\title{
Women's prospects for career advancement: Narratives of women in core mining positions in a South African mining organisation
}

\begin{tabular}{|c|c|}
\hline \multicolumn{2}{|c|}{$\begin{array}{l}\text { Authors: } \\
\text { Kgope P. Moalusi }{ }^{1} \\
\text { Candice M. Jones }^{1}\end{array}$} \\
\hline \multicolumn{2}{|c|}{$\begin{array}{l}\text { Affiliations: } \\
{ }^{1} \text { Department of Industrial and } \\
\text { Organisational Psychology, } \\
\text { University of South Africa, } \\
\text { Pretoria, South Africa }\end{array}$} \\
\hline \multicolumn{2}{|c|}{$\begin{array}{l}\text { Corresponding author: } \\
\text { Kgope Moalusi, } \\
\text { moalukp@unisa.ac.za }\end{array}$} \\
\hline \multicolumn{2}{|c|}{$\begin{array}{l}\text { Dates: } \\
\text { Received: } 02 \text { July } 2018 \\
\text { Accepted: } 30 \text { Oct. } 2018 \\
\text { Published: } 15 \text { Apr. } 2019\end{array}$} \\
\hline \multicolumn{2}{|c|}{$\begin{array}{l}\text { How to cite this article: } \\
\text { Moalusi, K.P., \& Jones, C.M. } \\
\text { (2019). Women's prospects } \\
\text { for career advancement: } \\
\text { Narratives of women in core } \\
\text { mining positions in a South } \\
\text { African mining organisation. } \\
\text { SA Journal of Industrial } \\
\text { Psychology/SA Tydskrif vir } \\
\text { Bedryfsielkunde 45(0), } \\
\text { a1564. https://doi.org/ } \\
\text { 10.4102/sajip.v45i0.1564 }\end{array}$} \\
\hline \multicolumn{2}{|c|}{$\begin{array}{l}\text { Copyright: } \\
\text { ( ) 2019. The Authors. } \\
\text { Licensee: AOSIS. This } \\
\text { is licensed under the } \\
\text { Creative Commons } \\
\text { Attribution License. }\end{array}$} \\
\hline \multicolumn{2}{|l|}{ Read online: } \\
\hline 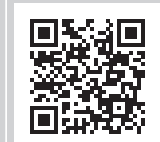 & $\begin{array}{l}\text { Scan this QR } \\
\text { code with your } \\
\text { smart phone or } \\
\text { mobile device } \\
\text { to read online. }\end{array}$ \\
\hline
\end{tabular}

Orientation: Even though there has been a phenomenal increase in the number of women employed in the mining industry, the figures hide many gender inequalities as the gendered impediments to career advancement persist despite South Africa's remarkable equity policy regime. However, it is unclear, from the perspective of the women themselves, how their career advancement is encumbered.

Research purpose: This study reflects on the prospects for career advancement by exploring the work and organisational experiences of women in core mining positions in an open-cast mining organisation in South Africa.

Motivation for the study: To reflect on the prospects for career advancement of women in core mining positions.

Research approach, design and method: Eight professional women, selected through a purposive sampling procedure, participated in in-depth unstructured interviews. Data were analysed using Creswell's simplified version of the Stevick-Colaizzi-Keen method, guided by the lens of gendered organisations.

Main findings: Three themes emerged: (1) male domination that has marginalised women and compelled them to emulate masculinity has legitimised existing gender barriers, (2) the long, awkward and unpredictable hours of work have deepened women's time constraints because they have to combine the home or family caretaker role with work, and (3) the essence of being a woman in a mining organisation.

Practical/managerial implications: The study may present South African managers with a better understanding of how work and organisational features, policies, daily practices and discourses impede career advancement of women in core mining positions. Organisations should train managers to create conditions that minimise barriers and maximise performance and advancement, and align retention strategies.

Contribution/value-add: This study builds on existing knowledge about career advancement of women by providing new and valuable information specific to women in core mining positions in an open-cast mining organisation in South Africa, seen through the lens of gendered organisational theory. The findings highlight the need for organisational theory research that is responsive to the subtle issues and gendered assumptions that sustain encumbrances to women's career trajectories.

Keywords: Career advancement; women in core mining positions; gender; male domination; working hours.

\section{Introduction}

Many women continue to struggle in organisations, and their career progress has stalled because their work and organisational conditions tend to be hampered by their life patterns (Cha, 2013; McKie \& Jyrkinen, 2017; Tomlinson et al. 2013; Wyatt \& Sylvester, 2015). Career progression is described as the vertical or horizontal advancement of individuals inside and outside the organisation (Faugoo, 2011; Matthews, Monk-Turner, \& Sumter, 2010). Women experience more encumbrances in their career paths than men, intimating that work and organisations are not experienced the same way by women and men and are therefore not gender-neutral (Acker, 2012). Gender-neutrality cannot be professed when advantage and disadvantage in organisations are patterned through and in terms of a distinction between women and men (Acker, 1990, 2006). 
Mining in general, and the core mining positions in particular, has traditionally been a male-dominated field in South Africa (Botha, 2017; Botha \& Cronjé, 2015a, 2015b; Zungu, 2013). Core mining positions encompass mining, metallurgy, geology and engineering, among others (Harmony Gold Mining Company, 2008). The last 15 years have witnessed a phenomenal increase in the number of women employed in the mining industry (Minerals Council of South Africa, 2017). However, this increase conceals many gender inequalities, which are also acute in other male-dominated fields such as science, engineering and technology, legal practice and construction (Martin \& Barnard, 2013; McKie \& Jyrkinen, 2017; Pinnington \& Sandberg, 2013; Wallace \& Sheldon, 2013; Walsh, 2012; Wichert \& Steele, 2013).

Women continue to experience barriers to entry and career advancement because the work conditions remain unfavourable for them (Lahiri-Dutt, 2015; Steyl \& Koekemoer, 2011; Zungu, 2013). In South Africa, the dominant or contemporary organisational theory seeks to explain the encumbrances to women's career progress and advancement in terms of how women as individual employees are (un)able to balance work and life domains (Fernando, Amaratunga, \& Haigh, 2014; Watts et al., 2015). The theory feigns ignorance or has treated the subject of women and gender in organisations superficially (Acker, 2012; Dale \& Burrell, 2014). In this regard, organisational theory faces the threat of becoming redundant because it denies engagement with gender in organisations. The question of why gender inequalities persist in spite of government's policy, which proscribes discrimination against women, mandates equality and affirms women, can be grappled with by focusing on the 'invisible' barriers that women encounter in their career paths. The dominant organisational theory remains unresponsive to the subtle issues and gendered assumptions that sustain female disadvantage and male advantage. Acker (2012) refers to the notion of gendered substructure, which pertains to the invisible processes in the lives of organisations in which gendered assumptions about women and men are embedded and reproduced, and gender inequalities sustained. This study reflects on the prospects for career advancement by exploring the work and organisational experiences of women in core mining positions in an opencast mining organisation in South Africa, guided by the lens of gendered organisations.

\section{Gender inequitable impact of organisations in South Africa: Background and context}

South Africa has a remarkable gender policy regime that promotes gender equality and requires that no woman should be unfairly discriminated against. Specifically, legislation that bars discrimination against women, mandates equality and affirms women already exists in South Africa. South Africa's gender equality policy is underpinned by section 9 of the Constitution of the Republic of South Africa 108 of 1996
(Republic of South Africa [RSA], 1996b). The Promotion of Equality and Prevention of Unfair Discrimination Act 4 of 2000 (RSA, 2000a), the Employment Equity Act 55 of 1998 (RSA, 1998) and the Commission on Gender Equality Act 39 of 1996 (RSA, 1996a), inter alia, give effect to section 9 of the Constitution. Germane to the mining sector are the Mineral and Petroleum Resources Development Act 28 of 2002 (RSA, 2002) and the Broad-Based Socio-Economic Empowerment Charter for the South African Mining Industry (the Mining Charter) (RSA, 2004) and its subsequent revisions. They both proscribe the exclusion of women and require organisations to actively set specific targets to increase the number of women in their employment.

However, the statistics show that organisations affect the lives of women and men differently, and much still needs to be done to overcome the barriers of gender equality in the South African workplace. In 2015, women accounted for 51\% of the population and $45 \%$ of economically active individuals in South Africa (Statistics South Africa, 2015). In the same year, women's employment stood at 37\% compared to $49 \%$ for men (Statistics South Africa, 2015), while during the first quarter of 2016, $40 \%$ of women had access to pension fund contributions compared to $49 \%$ of men (Statistics South Africa, 2016). However, the overall number of women working in the mining sector has increased in the past 16 years - from 11400 in 2002 to more than 53179 in 2017, representing $12 \%$ of the total labour force (Minerals Council of South Africa, 2018). The skilled technical professions account for $18 \%$ of women employees (Minerals Council of South Africa, 2018). Research shows that the mining sector is not gender-neutral because a host of job, work and organisational structures, procedures and processes affect women adversely (Botha \& Cronjé, 2015a, 2015b; Zungu, 2013). It is for this reason that this study endeavours to reflect on the prospects for career advancement by exploring the work and organisational experiences of women in core mining positions in an open-cast mining organisation in South Africa, using the lens of gendered organisations.

\section{Theorising gender and organisations: Sources of women's disadvantage explained}

According to Smith et al. (2016), mining is a notoriously dangerous occupation; however, men and women are exposed and affected differently. Women encounter a variety of impediments to career advancement in the mining industry (Botha, 2017; Botha \& Cronjé, 2015a, 2015b; Zungu, 2013). The unique challenges encountered in the mining industry include the hazards that endanger the health and safety of women, safety and protective equipment for women that are largely designed to fit the male body, male domination that makes it difficult for women's voices to be heard, sexual harassment in the mine pits and the persistent gender inequality that typifies the industry. For example, in male-dominated work settings, males may not share sensitivity with their women 
counterparts on a plethora of issues such as harassment. Gender domination manifests as harassment, which is connected with those actions or omissions that make women uncomfortable, such as 'guys talk' (Tomlinson et al., 2013). Sexual harassment of women has also been reported in the mine pits, with inadequate legal redress (Lahiri-Dutt, 2015). Sexual harassment has the effect of constraining women in their quest for professional credibility and career advancement (Williams, Muller, \& Kilanski, 2012). Sometimes women may regard the sexist jokes as nothing personal but humour, but as Sang and Powell (2012) said, such humour reinforces negative gender perceptions by virtue of presenting women as inferior. The sexist remarks and jokes that are presented as humour also become difficult to challenge (Sang \& Powell, 2012).

The career trajectories of women in male-dominated occupations are encumbered, which has resulted in fewer women remaining and advancing through the ranks of organisations (Walsh, 2012; Woolnough \& Redshaw, 2016). These encumbrances persist in spite of government policy proscribing discrimination and affirming women. Martin (1994) observes that well-intentioned policies that simply call for increases in the number of female employees continue to fail because jobs and organisations are structured in a manner that promotes disadvantage for women and advantage for men. Consequently, many women continue to be perceived as 'a disappointment' and 'not living up to their potential' because the structuring of jobs and organisations presents them with formidable obstacles to continued employment and promotion (Martin, 1994).

As discussed earlier, the subject of gender in South African organisations has received scant attention because the gender-neutral and asexual industrial and organisational (I-O) psychology discourse dominates organisational analysis and theory. The notion that jobs and hierarchies are genderneutral and asexual ignores gender, the body and sexuality as complex components of the processes of control and domination in organisations (Acker, 1990, 2012). The genderneutral and asexual discourse portrays the worker as an abstract, disembodied and asexual individual (Acker, 1990; Nemoto, 2013). Such an ideal being exists only for the job and does not have other imperatives of existence that fall outside the boundaries of the job, as these may interfere with job performance and render the incumbent unsuitable for the abstract and gender-neutral job. The ideal worker has minimal or no care for children, and a spouse or another person caters for any of their other needs (Acker, 1990).

Unlike male bodies, which have minimal responsibility in terms of procreation, women's bodies and their capacity to procreate and breastfeed disqualify women from the notion of an ideal worker. The legitimate responsibilities of childbearing and childrearing are considered non-work imperatives that are antithetical to the demands of an abstract and gender-neutral job (Acker, 1990, 2012). The abstract and disembodied worker is thus constructed from a male body.
This absence of sexuality and procreation in organisational logic obscures and helps reproduce underlying gender relations (Acker, 1990). For example, the male worker's commitment to the job and the organisation is deemed to be higher, and he is expected to shoulder positions of greater responsibility and authority than a female worker, whose commitment is divided between work and home or family responsibilities (Acker, 1990; Banihani, Lewis, \& Syed, 2013).

Gendered subtext and gendered organisational logic reveal how gendered identities account for the belief that men and women are different and that work should be divided according to gender (Acker, 2012). For example, the home is regarded as the place where women express their nurturing and caring skills by caring for babies and raising children because they are thought to be nurturing and caring (Acker, 1990; Handy \& Rowlands, 2014; Kristensen et al., 2017). Similarly, the division of work by gender locates paid work in organisations - entities that are fundamentally different from the location of most unpaid work; that is, the home. The ideological separation of the domains of men (work/ public) and those of women (home/private) reflects the structural separation of production and reproduction and perpetuates the embedded notions of masculinity and femininity (Acker, 2012; Martin, 1994). The public-private dichotomy disadvantages women because they perform most of the so-called private work. However, many women perform public-sphere, paid work during the day, and when they arrive home they take the 'second shift' of unpaid childcare and housework (Blair-et al., 2015; Hochschild, 1989; Kristensen et al., 2017; Martin, 1994). According to Hochschild (1989), the 'second shift' stalled the gender equality revolution.

It may be argued that, based on their heterogeneous career or life stages, women face different issues and life tasks at different career and life stages (Sullivan \& Mainiero, 2007). For example, women in the mid-career stage experience more difficulties in advancing their careers because of the saliency of the caretaker role such as childrearing compared to women in the late career and life stage (McFaden \& Swan, 2012). However, regardless of their career-life stage, most women inevitably face challenges not typically shared by their male counterparts. While the numbers are increasing as more women enter male-dominated occupations and economic sectors, fewer women advance into the upper hierarchies because of these unique challenges.

A host of barriers curtail female employees' prospects for career advancement, more than they do for men (Nemoto, 2013; Wallace \& Sheldon, 2013; Walsh, 2012; Wichert \& Steele, 2013). In I-O psychology, the prospects for career advancement of women have been explained in terms of how women as individual employees are (un)able to balance work and life domains (Fernando et al., 2014; Watts et al., 2015). This viewpoint is akin to the phenomenon of blaming, in which the victims of crime are held accountable for what happened to them. The phenomenon of blaming persists because I-O psychology has treated the subject of women and gender 
superficially. The framing of questions germane to women's career advancement conceals the unique challenges facing women in core mining positions in South Africa (Acker, 2012; Dale \& Burrell, 2014).

\section{Goal and contribution of the study}

The purpose of this study was to reflect on the prospects for career advancement by exploring the work and organisational experiences of women in core mining positions in an open-cast mining organisation in South Africa. The specificity of the sample and the mining organisation, together with the paucity of research on women's experiences in open-cast mining organisations in South Africa, make this study novel and significant because, while the challenges common in traditional deep-shaft mining and the physical demands of core mining positions are pertinent, they are less significant in an open-cast mine. The question of why gender inequitable prospects for career advancement persist in spite of mining organisations' commitment to gender equality and governments' policy (which proscribes discrimination against women, mandates equality and affirms women) becomes fundamental. As it has been recognised in the existing literature, the situation of women in mining is underrecognised and under-theorised (Jenkins, 2014). Guided by the lens of gendered organisations, the invisible processes in the life of the organisation, in which gendered assumptions about women and men are reproduced and gender inequalities are sustained, are problematised. The aim is to generate new insights that could lead to managers' and other stakeholders' insightful understanding of women's experiences and career prospects in an open-cast mining organisation.

This study provides valuable insight into the experiences of women in core mining positions, amplifying the fact that the encumbrances to career advancement cannot be fully explained in terms of how women as individuals are (un)able to balance work and life domains because the impediments are unique to the lives of women. Mining organisations need to change so that they are premised, and support the new 'ideal worker' who has gender and sexuality and is involved in both work and home or family.

\section{Research design \\ Research approach and strategy}

In this study, a qualitative and constructivist research approach was followed to reflect on the prospects for career advancement by exploring the work and organisational experiences of women in core mining positions in an opencast mining organisation in South Africa. The study operated from the premise that women's work and organisational experiences and the prospects for career advancement can be best understood from their point of view and not that of the researchers. The purpose of the study was not to search for 'truth' about the participants' experiences but to ascertain how they, individually and subjectively, make meaning from such experiences (Davis \& Michelle, 2011;
Grant \& Giddings, 2002). The strength of qualitative research lies in an in-depth understanding of phenomena under investigation, such as the experiences of women in core mining positions. Ontologically, the study was premised on the view that reality was relative because the women in core mining positions individually constructed their own subjective, operational worlds relating to work and organisational experiences (Burrell \& Morgan, 1979; Davis \& Michelle, 2011). Epistemologically, knowledge is regarded as softer and subjective as it lies within the individual experiences of the participants.

\section{Research setting, entrée and researcher roles}

The open-cast mining organisation mines and beneficiates minerals and employed metallurgists, geologists, and mechanical and electrical engineers. However, the metallurgists dominate because they run the business processes. The choice of the research setting was based on opportunity and convenience as the second author was employed in the human resources department to implement and facilitate business strategies related to the organisation's human resources. For this reason, an overt or direct approach to entrée was made because it raises few ethical problems and is less difficult (Jorgensen, 2011). Permission to conduct the study was obtained from the organisation. The research setting was more or less open as it required little negotiation (Jorgensen, 2011). The second author facilitated data collection, transcription and analysis. However, the first author had to familiarise himself with and immerse himself in the data to effectively participate in the full data analysis and completion of the manuscript.

\section{Sample}

A non-probability and purposive small sample of eight women participated in the study. Small samples are suitable for exploring lived experiences regarding a specific social phenomenon through in-depth interviews (Creswell, 2003). However, theoretical saturation in the study occurred with the eighth interview. Theoretical saturation occurred because the data from the interviews became repetitive (Groenewald, 2004). Only individuals who satisfied the following criteria relevant to the research objectives participated in the study (Guest, Bunce, \& Johnson, 2006): they had to be women who occupied core mining positions, possessed a formal post-grade 12 qualification (a bachelor's or BTech degree), a minimum of 3 years' experience in the mining environment and had to be in specialist or supervisory roles. The organisation had 1728 permanent employees throughout South Africa, with women comprising $14.5 \%$ of the total workforce, with the majority of them occupying non-core administrative positions. Table 1 shows the biographical information of the participants.

\section{Data collection}

Data were collected through unstructured individual interviews, which took on average $60 \mathrm{~min}$ to complete. According to Creswell $(2003,2009)$, open-ended interviews 
TABLE 1: Biographical information of the participants.

\begin{tabular}{llll}
\multicolumn{4}{l}{ TABLE 1: Biographical information of the participants. } \\
\hline Business area & Position & Population group & Marital status \\
\hline Mineral separation plant & Metallurgist & White population & Married \\
Mineral separation plant & Metallurgist & White population & Single \\
Smelter & Metallurgist & Mixed race population & Single \\
BSB & Metallurgist & African population & Single \\
BSB & Metallurgist & Mixed race population & Single \\
Smelter & Senior metallurgist & White population & Married \\
BSB & Geologist & White population & Married \\
Mineral separation plant & Senior metallurgist & Mixed race population & Married \\
\hline & & &
\end{tabular}

allow for probing deeper into the participants' experiences to develop in-depth insight into the phenomenon under investigation. Unstructured interviews provide researchers with an opportunity to probe and develop insight into issues that had not been anticipated (Englander, 2012). The disadvantages are that the interviews were time-consuming and expensive (Chesebro \& Borisoff, 2007; Richards \& Morse, 2007).

\section{Data analysis and interpretation}

Creswell's (2007) simplified version of the Stevick-ColaizziKeen method was used to further analyse the data collected. This involved a process of familiarisation with and immersion in the data. Significant statements of the transcribed interviews were then listed and grouped together to form themes. A full description was written using the experiences of the participants. Examples of verbatim statements were used to express and contextualise these experiences. A description of how these experiences had occurred was formulated to allow the setting to be clarified. Finally, an amalgamated description of the phenomena was written to describe the work and organisational experiences of the women in core mining positions and to reflect on their prospects for career advancement on the basis of their experiences. During the data analysis process, the researchers were conscious of their own experience of the phenomenon, but endeavoured to focus on the lived experiences of the participants. However, qualitative research is about the interpretation of what the researchers hear and see - hence, the researchers' interpretations cannot be separated from their own background, history and prior understandings (Creswell, 2007).

\section{Strategies employed to ensure data quality and integrity}

Data quality was ensured within an ethical framework that included permission from the participating organisation, informed consent, voluntary participation and the right to withdraw, anonymity, confidentiality, ethical clearance and rigorous analysis of the data. All the data transcripts were stored safely on a password-protected computer, and on the data mass-storage devices of the researchers.

\section{Ethical considerations}

The University of South Africa's Ethics Research Committee granted ethical clearance to conduct the study.

\section{Findings}

Three major themes emerged from the women's narratives. These themes revealed that the prospects for the career advancement of women in core mining positions were encumbered primarily by: (1) male domination that marginalised women and compelled them to emulate masculinity and legitimised existing gender barriers, (2) the long and awkward hours of work, which deepened their time constraints because they combined the home or family caretaker role with work, and (3) being a woman in a mining organisation. The three themes, together with the accompanying verbatim quotes, are summarised in Table 2 to provide a clear overall perspective of the findings.

\section{Theme 1: Male domination and masculinity}

Women comprised a meagre $14.5 \%$ of the total workforce of the organisation. However, the overwhelming majority of them were not occupying the core mining positions. Male dominance and the masculinity culture are entrenched in the core mining positions of the organisation. Describing male domination of the core mining positions, Participant 5 reported that she was the only female entitled to attend the professional meetings in a room full of men. The males in the meeting did not seem to share an appreciation for diversity and respect for differences because they employed strategies that were demeaning and aimed at suppressing the contributions of women. These strategies have the effect of marginalising the female voice, adversely impacting the confidence in their own abilities and self-concept, and thus sustaining male domination and control.

In a South African workplace milieu that purports to prohibit discrimination against women and affirm them, males are in control of the upper hierarchies and overlook women in core mining positions for promotion. Despite the requirements in terms of legislation and the Mining Charter to increase the number of women in the organisation's employment and the rarity of finding a mixed race metallurgist with her experience, male managers precluded women like Participant 3 from occupying high-level positions (Participant 3). The case of Participant 8, who was already a senior metallurgist, may imply the organisation's lack of concern for improving her skills in her current job and facilitating their development for future assignments and opportunities. Not knowing 'what you need to do to get to the top' may suggest that the organisation may not be concerned about one's current performance or long-term future and may lead women like Participant 8 to seek better opportunities elsewhere.

In masculine workplace cultures like this mining organisation, women lament the absence of female role models. In the view of Participant 8 , the scarcity of female role models tends to undermine the very notion of career advancement as male managers would:

\footnotetext{
'... always think that a female is going to have to prove herself 10 times more than what a male has to'. (Participant 8, female, senior metallurgist, married)
} 
TABLE 2: Themes and verbatim quotes.

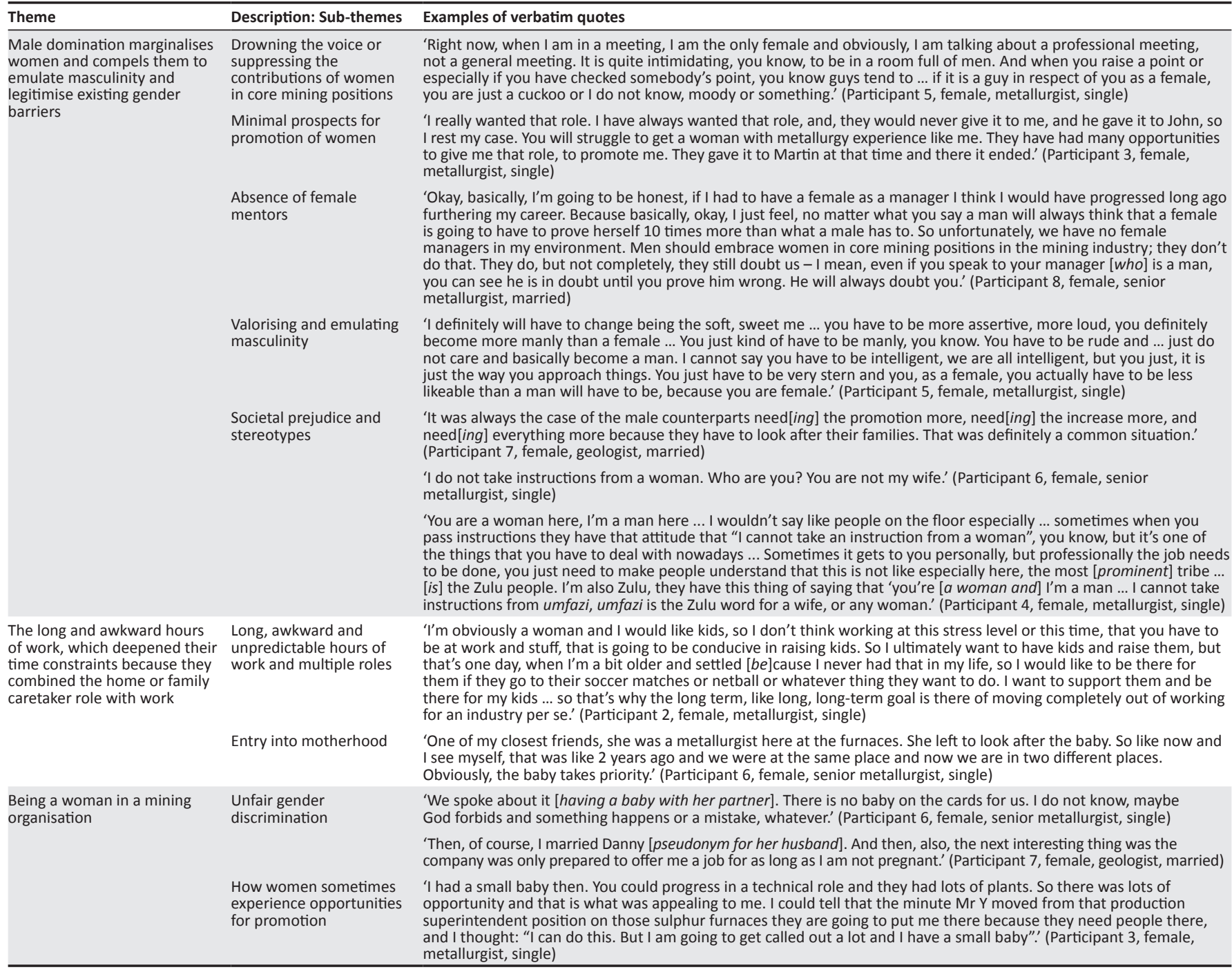

The participants, specifically participants 2 and 8 , experienced the organisation as being gender-biased because to advance their careers in the organisation they had to valorise and emulate masculinity, making men the norm. Males mobilised masculinities by elevating masculine characteristics such as loudness and aggressiveness. Participant 5 felt that they had no option but to emulate the masculinity dominating the organisation if they were to stay on what is perceived as the masculine career paths. In this mining organisation, masculinity is given expression by not only the genderbiased promotions and veneration of masculine traits, but also the notion of males being regarded as breadwinners who need to take care of their families. This practice confers gender superiority to men and expresses the perceived inferior worth of women (who are considered caregivers associated with unpaid homework) relative to men, and implies that women do not have the same need as men as far as compensation is concerned. However, it is also evident from the explanation of Participant 6, a senior white metallurgist, that masculinity and gendered identities are also brought into organisations by employees who are members of the community and share society's prejudice and stereotype attributions regarding what it means to be a man or a woman. In the view of Participant 4, a black or African metallurgist, the prejudice seemed stronger amongst certain social groups. However, the reports that the women had to stand firm because male subordinates would resist or refuse to take instructions from women in core mining positions may denote what masculinity symbolises for males - selfrespect for men at the bottom and power for men at the top but confirms the gender superiority of both (Acker, 1990). The narratives of the women in core mining positions suggest that gender and sexuality may be two essential constituent elements of any discourse geared towards understanding the career advancement encumbrances unique to women in this organisation.

\section{Theme 2: Long, awkward and unpredictable hours of work and home or family caretaker role}

In exploring the work and organisational experiences of women in core mining positions, it became evident that the hours of work were perceived as not gender-neutral because they imposed hardships on women. The participants described the unfavourable hours of work in terms of the long working hours, the shift system that imposed awkward working hours and the standby system with unpredictable 
hours. These working hours were perceived as antithetical to work-life balance because they deepened the women's time constraints because they have disproportionate multiple home or family responsibilities such as childrearing.

The standby and awkward hours of work, such as going to work at 02:00, were experienced as being particularly unfavourable to raising children by Participant 4 . The long hours of work meant that the women in core mining positions had little time for work-related activities because of multiple demands on their time. Participant 1 sacrificed personal time for work-related activities and felt that the time constraints she experienced have the capacity to impede her career trajectory.

Participant 2 indicated that women do not have a choice but are compelled by the work conditions that encompass long, awkward and unpredictable hours to postpone marriage or pregnancy if they are to make it in this masculine career, momentarily becoming like the ideal worker who lives for the job.

\section{Theme 3: Being a woman in the mining organisation}

Intertwined with the two preceding themes is the notion of being a woman in the mining industry as women have to contend with numerous gender-related challenges. Despite the barriers that continue to encumber the career trajectories of women, the South African mining industry has made tremendous progress in increasing female employees. Participant 7 revealed that at one stage in her career, her employer was prepared to offer her a job - as long as she did not fall pregnant. Entry into motherhood had ramifications not only for the career advancement of women in core mining positions, but also for their continued employment.

In considering opportunities for promotion, women, like men, have to be concerned about whether it could be a deadend job, has the right challenging responsibilities, is in harmony with one's lifestyle and more. For example, the idea that not all promotions are worth taking seemed more real for Participant 3, who had not applied for a higher level position because she had a small baby to raise and was concerned that she would be called in more often if she was appointed. Being a woman in the mining organisation has its unique challenges. The women's narratives demonstrate that in this organisation, the whole process of organising, including a person's job, is not gender-neutral and asexual, because women and men are affected differently.

\section{Discussion}

The findings of this study revealed the work and organisational experiences that are unique to women in core mining positions and have the capacity to encumber their career trajectories. The accounts of women in core mining positions revealed that their experiences were typified by: (1) male domination that marginalised women and compelled them to emulate masculinity that has legitimised existing gender barriers, (2) the long and awkward hours of work, which deepened their time constraints because they combined the home or family caretaker role with work, and (3) being a woman in the mining organisation curtailed advancement opportunities. These experiences were not likely to be faced by their male counterparts in the mining organisation. With this last statement, the authors pre-empted the central aim of the study, namely to reflect on the prospects for career advancement in view of the work and organisational experiences of women in core mining positions in an opencast mining organisation in South Africa.

Clearly, the organisation is male dominated and typified by pervasive and dominant masculinity personified by the marginalisation and exclusion of women in core mining positions from the upper hierarchies. Marginalisation and exclusion occurred when the voices of women in core mining positions were suppressed in crucial meetings and when their aspirations for promotion were frustrated by those practising masculinity. When masculinity is practised, the gendering of the core mining positions is deepened and the system of male privilegebecomes more entrenched, even when an organisation's policy prohibits gender discrimination. Previous research suggests that males may practise masculinity to marginalise women by blocking their career paths because women are regarded as a threat to the power they wield (Banihani et al., 2013; Martin, 2001). By marginalising women in core mining positions and compelling them to emulate masculinity, the existing gender barriers in the organisation become legitimised.

Previous researchers have illustrated that through selection and promotion, women experience discrimination despite the existence of organisational policies to overcome gendered practices (Howe-Walsh \& Turnbull, 2016). Despite the organisation operating within a South African legal framework that prohibits gender discrimination and affirms women, the women in core positions experienced direct and indirect discrimination. Nemoto (2013) cautions that the antidiscrimination policies may not always prevent gender bias as corroborated by the 'invisible' barriers that women encounter in their career trajectories. As observed in this study, and in support of the existing literature, when organisations create female disadvantage and male advantage, women's prospects for career advancement are curtailed (Acker, 1990, 2012; Kristensen et al., 2017; Martin, 2001). Despite the vast potential to contribute positively to the goals of the organisation, women like Participant 3 find it difficult to 'crack' the glass ceiling (Davis \& Maldonado, 2015).

The deliberate frustration of women's aspirations for promotion lowers their morale. However, when this occurs repeatedly, it ceases to be a morale issue and sends a message that the organisation does not value women. After being turned down twice for promotion, Participant 3 articulated that despite the rarity of finding a woman with metallurgy experience:

\footnotetext{
'... they would never give it [the position] to me.' (Participant 3, female, metallurgist, single)
} 
Such negative organisational experiences have the potential to make her reluctant to contest for future promotions because she has to relive the negative experience - like returning to the scene of an accident (Howe-Walsh \& Turnbull, 2016). The impact of recurring negative experiences is that they are likely to wreak havoc in Participant 3's confidence in her own abilities. Such organisational experiences minimise the career-enhancing opportunities of women in core mining positions, because of their enormous impact on women's self-confidence.

The reported absence of guidelines on how to rise to the top exacerbated the frustrations that women experienced regarding the lack of promotion. The absence of promotion guidelines obfuscated the alignment of the women's career trajectories with the next level of seniority (Howe-Walsh \& Turnbull, 2016). In the absence of guidelines that described the pathway to top hierarchies, failure to secure promotions raises questions not only about the organisation, but also about women's own abilities. Previous researchers report that such experiences of failure among women employees create perceptions of inability and doubt that promotion or success is possible (Howe-Walsh \& Turnbull, 2016). This experience reinforced women's perceptions that the prospects for career advancement for women were limited.

A culture of masculinity in the organisation is discernible from the manner in which masculine principles and behaviours are valorised and femininity is shunned. The women in core mining positions were expected to mimic and model their behaviour around that of their male counterparts, making male the criterion. As one participant said, women were expected 'to change being the soft, sweet me, to become more manly than a female, to be rude and become a man'. This finding lends credence to $\mathrm{O}^{\prime} \mathrm{C}$ Connor, $\mathrm{O}^{\prime}$ Haggen and Brannen's (2015) observation that doing showing masculinity in organisations reinforces gender stereotypes as it places greater value on masculinity than femininity. This practice resonates with Acker's $(1990,2012)$ notion of the ideal worker, who is always constructed from a male body and his identity is always masculine. Women in core mining positions have to follow the male work-behaviour patterns if they are to satisfy the organisation's work-performance standards. However, idealising male attributes marginalises women who cannot achieve the qualities of an ideal worker because to do so would be to become like a man (Acker, 1990). The masculine principles are an embodiment of the dominant male and negate the view that organisations are gender-neutral social institutions (Howe-Walsh \& Turnbull, 2016; Nemoto, 2013). Gender bias precludes women from attaining equal career advancement prospects or outcomes compared with their male counterparts because organisations affect women differently (Martin, 1990). Previous researchers have shown that gender bias manifests when female employees have to emulate masculinity (Nemoto, 2013). Gender bias originates in organisational cultures, expectations and everyday organisational practices that unintentionally favour men over women and result in invisible barriers to the career advancement of women (Ellemers, 2014).
The notion of men as breadwinners has reinforced discrimination against women in this mining organisation. Such patriarchal and archaic beliefs subtly discriminate against women - they state that a man is the head of the family and needs to support them. Women do not have the same needs as men as far as career advancement and the concomitant compensation are concerned (Berdahl \& Moon, 2013; Carr et al. 2015). As components of gender-role ideology, these beliefs reflect more than what are appropriate roles for women and men because they confirm men because more valued than women (Acker, 2012).

The findings of the study revealed that the hours of work, epitomised by the long, awkward and unpredictable hours of the organisation, deepened the women's time constraints because they are expected to fulfil dual roles as an ideal caretaker and worker - challenges not faced by most men. The women in core mining positions expressed the fact that they were overburdened with home and family responsibilities. The deleterious consequences of the continued imbalance in the sharing of domestic responsibilities between women and men have been noted in previous research (Groysberg \& Abrahams, 2014).

However, women have to cope with their hours of work because most organisations feign obliviousness to their double burdens, and women do not receive time off for home and family responsibilities. The women's experiences revealed that the hours of work were more suitable for male life patterns. However, previous researchers have unveiled how hours of work are socially constructed along gendered life cycles (Kristensen et al., 2017). Hours of work are constructed around the ideal worker who is essentially a man because he is unencumbered by home and family responsibilities. Many women perform public sphere work during the day, for a wage, and when they arrive home they take the unpaid 'second shift' work that involves childcare and housework (Hochschild, 1989; Kristensen et al., 2017; Martin, 1994; Nelson \& Burke, 2000). Women and men devote significantly different time to work and family, deepening the intensity of women's struggles to balance their dual roles as workers and caretakers. However, women in core mining positions have to follow the male work norm of time discipline by subordinating their caretaker role to the organisation and work (Nemoto, 2013).

The participants narrated how the interplay between the hours of work and the home or family burden constrained their prospects for career advancement. It was not easy for the women in core mining positions to have a baby and work in the prescribed hours. Participant 6 recounted how one of her closest metallurgist friends had left the company upon entering motherhood because her baby became her priority. This finding resonates with existing research, indicating that a commitment to family and home responsibilities encumbered women's advancement (Howe-Walsh \& Turnbull, 2016). As articulated by participants 6 and 7, women anticipate the implications of marriage and pregnancy for their careers. However, as evidenced by the findings of this study, women 
are presented with situations in which they have to choose (when in fact they do not have a choice) between their career and family (Chawla \& Sharma, 2016; McIntosh, McQuaid, \& Munro, 2014). As some studies suggest, women postpone marriage or pregnancy until their careers are established (Acker, 2006; Carr et al., 2015).

Previous research reveals that organisations that are typified by working hours similar to this mining organisation share negative masculine stereotypes against employees who are perceived as caretakers and not ideal workers (Nemoto, 2013). Ideal workers work long hours because they are unencumbered and are able to complete the work. However, because working long hours may be undesirable for most women, or they may not be able to work long hours, they are perceived as less devoted and committed to their work and the organisation. Masculine traits such as endurance, toughness and commitment are attached to the heroic and ideal worker who exists for the job and does not allow non-work imperatives to interfere with job performance (Acker, 2012; Nemoto, 2013). These stereotypes militate against the career advancement of women as they are least likely to be preferred candidates for selection and promotion. However, it is also worth noting from the findings of this study that some women decline opportunities for promotion because it may imply working longer hours. This finding lends credence to reports that women decline promotions because of what it may imply for their work-life balance (Nemoto, 2013).

\section{Conclusion}

The purpose of this study was to reflect on the prospects for career advancement by exploring the work and organisational experiences of women in core mining positions in an open-cast mining organisation in South Africa. Guided by the lens of gendered organisations, the invisible processes and gendered assumptions about women and men were problematised. While the study is exploratory in nature, its findings have the potential to contribute to the theory and practice of I-O psychology. Practical implications for I-O psychologists and organisations include becoming aware of the issues that encumber the career trajectories of women in core mining positions. Psychologists and organisations should realise that the anti-discrimination policies may not always prevent gender bias and should be ready to grapple with the 'invisible' barriers. The lack of action may relay the message that the organisation does not value women, or it adversely affects the confidence that women have in their own abilities. In order to provide solutions to overcome women's career impediments, I-O psychologists and organisations should embed the perspectives of women in the design of jobs, and organisational structures and processes, as well as organisational practices across organisational hierarchies to facilitate the creation of gender equity, which is essential for women's career advancement. Industrial and organisational psychologists and organisations may develop training interventions or other organisational support practices to encourage and facilitate the development of values that appreciate and respect differences and eliminate gender-based career advancement barriers. The mining organisation should work to appoint in senior roles women role models who can serve as coaches, teachers and openers of doors for the women in core mining positions.

As with most studies, this study has some limitations. The data from the eight participants do not represent the experiences of all women in core mining positions because the sample does not reflect the breadth of the women in core mining positions. The sample comprised predominantly metallurgists who happened to dominate the organisation because they ran the business processes. In other words, while the data were adequately analysed, its prevalence cannot be generalised. Perhaps a stratified, purposive sample should have been used, as suggested by Creswell (2009). However, as per the tenets of qualitative research, the goal was never to generalise the results of the study to the broader population, but instead to develop a working hypothesis. Following this, other researchers may develop appropriate research designs to investigate the prevalence or generalisability of the findings. It would have been useful to include men in core mining positions in the sample for purposes of comparison. However, in a South African political-legal milieu that prohibits discrimination against women and affirms them, understanding the experiences of women in core mining positions from their viewpoint is a challenging prospect for future research.

This study highlighted the encumbrances that preclude women in core mining positions from advancing their career goals. In light of the assertion that women's experiences are unique and subjective and not typically shared by their male counterparts, I-O psychology or traditional organisational theory should reframe the issue of women's career and advancement. This is because it cannot be fully explained in terms of how some individual women employees are (un) able to balance work and life domains as these experiences are unique to females. In studying women's career experiences, intersectionality may also be essential because race and class, for example, may matter.

\section{Acknowledgements}

The views expressed in this article are those of the authors and not the official position of the institution.

\section{Competing interests}

The authors declare that they have no financial or personal relationships which may have inappropriately influenced them in writing this article.

\section{Authors' contribution}

C.M.J. collected the interview data and arranged for the transcription. Data analysis was undertaken by both authors. K.P.M. used a portion of the data collected to develop the argument to a higher level because this study goes beyond the original research, using a new lens to interpret the data. 


\section{References}

Acker, J. (1990). Hierarchies, jobs, bodies: A theory of gendered organisations. Gender and Society, 4(2), 139-158. https://doi.org/10.1177/089124390004002002

Acker, J. (2006). Inequality regimes: Gender, class and race in organisations. Gender and Society, 20(4), 441-464. https://doi.org/10.1177/0891243206289499

Acker, J. (2012). Gendered organisations and intersectionality: Problems and possibilities. Equality, Diversity Inclusion: An International Journal, 31(3), 214-224. https://doi.org/10.1108/02610151211209072

Banihani, M., Lewis, P., \& Syed, J. (2013). Is work engagement gendered? Gender in Management: An International Journal, 28(7), 400-423. https://doi.org/10.1108/ GM-01-2013-0005

Berdahl, J. L., \& Moon, S. H. (2013). Workplace mistreatment of middle class workers based on sex, parenthood and caregiving. Journal of Social Issues, 69(2), 341-366. https://doi.org/10.1111/josi.12018

Blair-Loy, M., Hochschild, A., Pugh, A. J., Williams, J. C., \& Hartmann, H. (2015) Stability and transformation in gender, work, and family: Insights from the second shift for the next quarter century. Community, Work \& Family, 18(4), 435-454, https://doi.org/10.1080/13668803.2015.1080664

Botha, D. (2017). Barriers to career advancement of women in mining: A qualitative analysis. South African Journal of Labour Relations, 41, 15-32. https://doi.org/ analysis. South African Jou

Botha, D., \& Cronjé, F. (2015a). Occupational health and safety considerations for women employed in core mining positions. South African Journal of Human Resource Management, 13(1), 1-12. https://doi.org/10.4102/sajhrm.v13i1.652

Botha, D., \& Cronjé, F. (2015b). Physical ability of women in mining: Can they show muscle? The Journal of Southern African Institute of Mining and Metallurgy, 115, 659-667. https://doi.org/10.17159/2411-9717/2015/v115n8a1

Burrell, G., \& Morgan, G. (1979). Sociological paradigms and organisational analysis: Elements of the sociology of corporate life. London: Heinemann.

Carr, P. L., Gunn, C. M., Kaplan, S. A., Raj, A., \& Frend, K. M. (2015). Inadequate progress for women in academic medicine: Findings from the national faculty study. Journa of Women's Health, 24(3), 190-199. https://doi.org/10.1089/jwh.2014.4848

Cha, Y. (2013). Overwork and the persistence of gender segregation in occupations. Gender \& Society, 27(2), 158-184. https://doi.org/10.1177/0891243212470510

Chawla, S., \& Sharma, R. R. (2016). How women traverse an upward journey in Indian industry: Multiple case studies. Gender in Management: An International Journal 31(3), 181-206. https://doi.org/10.1108/GM-06-2015-0050

Chesebro, J. W., \& Borisoff, D. J. (2007). What makes qualitative research qualitative? Qualitative Research Reports in Communication, 8(1), 3-14. https://doi.org/ 10.1080/17459430701617846.

Creswell, J. W. (2003). Research design: Qualitative, quantitative, and mixed methods approaches (2nd edn.). Thousand Oaks, CA: Sage.

Creswell, J. W. (2007). Qualitative inquiry and research design: Choosing among the five approaches. Thousand Oaks, CA: Sage.

Creswell, J. W. (Ed.). (2009). Research design: Qualitative, quantitative, and mixed methods approaches (3rd edn.). Los Angeles, CA: Sage.

Dale, K., \& Burrell, G. (2014). Being occupied: An embodied re-reading of organisational 'wellness'. Organisation, 21(2), 159-177. https://doi.org/10.1177/135050841 2473865

Davis, D. R., \& Maldonado-Daniels, C. (2015). Shattering the glass ceiling: The leadership development of African American women in higher education. Advancing Women in Leadership Journal, 35, 48-64.

Davis, C. H., \& Michelle, C. (2011). Q methodology in audience research: Bridging the qualitative/quantitative 'divide'? Participations: Journal of Audience and the qualitative/quantitative 'divide'
Reception Studies, 8(2), 559-593.

Ellemers, N. (2014). Women at work: How organisational features impact career development. Policy Insights from the Behavioural and Brain Sciences 1(1), 46-54. https://doi.org/10.1177/2372732214549327

Englander, M. (2012). The interview: Data collection in descriptive phenomenological human scientific research. Journal of Phenomenological Psychology, 43, 13-35. https://doi.org/10.1163/156916212X632943

Faugoo, D. (2011). The advancement of women to top management positions in the human resource management domain: A time for change? International Journal of Business and Social Science, 2(20), 195-202.

Fernando, N. G., Amaratunga, D., \& Haigh, R. (2014). The career advancement of the professional women in the UK construction industry: The career success factors. Journal of Engineering, Design and Technology, 12(1), 53-70. https://doi.org/ 10.1108/JEDT-04-2012-0018

Grant, B. M., \& Giddings, L. S. (2002). Making sense of methodologies: A paradigm framework for the novice researcher. Contemporary Nurse, 13, 10-28. https:// doi.org/10.5172/conu.13.1.10

Groenewald, T. (2004). A phenomenological research design illustrated. International Journal of Qualitative Methods, 3(1), 42-55. https://doi.org/10.1177/160940 690400300104

Groysberg, B., \& Abrahams, R. (2014). Manage your work, manage your life. Harvard Business Review, March 2014, 2-10.

Guest, G., Bunce, A., \& Johnson, L. (2006). How many interviews are enough? An experiment with data saturation and variability. Field Methods, 18, 59-82. https:// doi.org/10.1177/1525822X05279903

Handy, J., \& Rowlands, L. (2014). Gendered inequality regimes and female labour market disadvantage within the New Zealand film industry. Women's Studies Journal, 28(2), 24-38.
Harmony Gold Mining Company. (2008). Harmony Sustainable Development Report. Retrieved from www.har.co.za/files/harmony_sd2008.pdf

Hochschild, A. (1989). The second shift: Working parents and the revolution at home. New York: Viking.

Howe-Walsh, L., \& Turnbull, S. (2016). Barriers to women leaders in academia: Tales from science and technology. Studies in Higher Education, 14(3), 415-428. https://doi.org/10.1080/03075079.2014.929102

Jenkins, K. (2014). Women, mining and development: An emerging research agenda. The Extractive Industries and Society, 1(2), 329-339. Retrieved from https://doi. org/10.1016/j. exis.2014.08.004

Jorgensen, D. L. (2011). (Ed.). Gaining entrée to a setting. In Participant observation. Sage. Retrieved from https://doi.org/10.4135/9781412985376

Kristensen, R. H., Kent, P., Warming-Rasmussen, B., \& Windsor, C. (2017). Do mother and father auditors have equal prospects for career advancement? International and father auditors have equal prospects for career advancement?
Journal of Auditing, 21, 1-10. https://doi.org/10.111//ijau.12074

Lahiri-Dutt, K. (2015). The feminisation of mining. Geography Compass, 9(9), 523-541. https://doi.org/10.1111/gec3.12229

Matthews, C., Monk-Turner, E., \& Sumter, M. (2010). Promotional opportunities: How women in corrections perceive their chances for advancement at work. Gender Issues, 27, 53-66. https://doi.org/10.1007/s12147-010-9089-5

Martin, J. (1990). Deconstructing organisational taboos: The suppression of gender conflict in organisations. Organisation Science, 1(4), 339-359.

Martin, J. (1994). The organisation of exclusion: Institutionalisation of sex inequality, gendered faculty jobs and gendered knowledge in organisational theory and research. Organisation, 1(2), 401-431. https://doi.org/10.1287/orsc.1.4.339

Martin, P. Y. (2001). Gendering practices, practicing gender at work. Gender and Society, 17(3), 342-366. https://doi.org/10.1177/0891243203017003002

Martin, P., \& Barnard, A. (2013). The experiences of women in male-dominated occupations: A constructivist grounded theory inquiry. South African Journal of Industrial Psychology, 39(2), 1-12. https://doi.org/10.4102/sajip.v39i2.1099

McFaden, J. R., \& Swan, K. T. R. (2012). Women during midlife: Is it transition or crisis? Family and Consumer Sciences Research Journal, 40(3), 313-325. https://doi. org/10.1111/j.1552-3934.2011.02113.x

McIntosh, B., McQuaid, R., \& Munro, A. (2014). The impact of gender perceptions and professional values on women's careers in nursing. Gender in Management: An International Journal, 30(1), 26-43. https://doi.org/10.1108/GM-12-2013-0135

McKie, L., \& Jyrkinen, M. (2017). MyManagement: Women managers in gendered and sexualised workplaces. Gender in Management: An International Journal, 32(2), 98-110.

Minerals Council of South Africa. (2017). Women in mining in South Africa: Fact sheet Retrieved from www.mineralscouncil.org.za/industry-news/publications/.../424women-in-mining

Minerals Council South Africa. (2018). Women in mining in South Africa: Fact sheet. Retrieved from www.mineralscouncil.org.za

Nelson, D. L., \& Burke, R. J. (2000). Women executives: Health, stress, and success. Academy of Management Executive, 14(2), 107-121.

Nemoto, K. (2013). Long working hours and the corporate divide in Japan. Gender, Work and Organisation, 20(5), 512-527. https://doi.org/10.1111/j.1468-0432.2012. 00599.x

O'Connor, P., O'Hagan, C., \& Brannen, J. (2015). Exploration of masculinities in academic organisations: A tentative typology using career and relationship commitment. Current Sociology, 63(4), 528-546. https://doi.org/10.1177/0011392115574859

Pinnington, S. H., \& Sandberg, J. (2013). Lawyers' professional careers: Increasing women's inclusion in the partnership of law firms. Gender, Work and Organisation, 20(6), 616-631.

Republic of South Africa (RSA). (1996a). Commission on Gender Equality Act 39 of 1996. Government Gazette, 24 July, Vol. 373, No. 17341, 2-18. Pretoria: Government Printer.

Republic of South Africa (RSA). (1996b). Constitution of the Republic of South Africa 1996. Government Gazette, 18 December, Vol. 378, No. 17678, 1-147. Pretoria: Government Printer.

Republic of South Africa (RSA). (1998). Employment Equity Act 55 of 1998. Government Gazette, 19 October, Vol. 400, No. 19370, 1-54. Pretoria: Government Printer.

Republic of South Africa (RSA). (2000). Promotion of Equality and Prevention of Unfair Discrimination Act 4 of 2000. Government Gazette, Vol. 556, No. 34701, 1-28. Pretoria: Government Printer.

Republic of South Africa (RSA). (2004). Scorecard for the Broad Based Socio-Economic Empowerment Charter for the South African Mining Industry. Government Gazette, Vol. 470, No. 26661, 3-17. Pretoria: Government Printer.

Richards, L., \& Morse, J. M. (2007). Users guide to qualitative methods. London: Sage.

Sang, K., \& Powell, A. (2012). Gender inequality in the construction industry: Lessons from Pierre Bourdieu. In S. D. Smith (Ed), Procs 28th Annual ARCOM Conference, 3-5 September, Edinburgh, UK: Association of Researchers in Construction Management, pp. 237-247.

Smith, N. M., Ali, S., Bofinger, C., \& Collins, N. (2016). Human health and safety in artisanal and small-scale mining: An integrated approach to risk mitigation. Journa of Cleaner Production, 129, 43-52. Retrieved from https://doi.org/10.1016/j. jclepro.2016.04.124

Statistics South Africa. (2015). Mid-year population estimates. Retrieved from https:// www.statssa.gov.za/publications/P0302/P03022015

Statistics South Africa. (2016). Quarterly labour force survey, Quarter 1: 2016. Retrieved from https://www.statssa.gov.za/publications/P0211/P02111stQuarter2017.pdf 
Steyl, B., \& Koekemoer, E. (2011). Conflict between work and non-work roles of employees in the mining industry: Prevalence and differences between demographic groups. South African Journal of Human Resource Management, 9(1), 1-14. https://doi.org/10.1402/sajhrm.v9i1.277

Sullivan, S. E., \& Mainiero, L. A. (2007). The changing nature of gender roles, alpha/ beta careers and work-life issues: Theory-driven implications for human resource management Career Development International, 12(3), 238-263. https://doi. mang/10.1108/13620430710745881

Tomlinson, J., Muzio, D., Sommerlad, H., Webley, L., \& Duff, L. (2013). Structure, agency and career strategies of white women and black minority ethnic individuals in the legal profession. Human Relations, 66(2), 245-269. https://doi.org/ in the legal profession. Hum

Wallace, M., \& Sheldon, N. (2013). Women and engineering: A workforce development issue. In R. Harris, \& T. Short (Eds.), Workforce development (pp. 113-129). Singapore: Springer. https://doi.org/10.1007/978-981-4560-58-0_7

Walsh, J. (2012). Not worth the sacrifice? Women's aspirations and career progression in law firms. Gender, Work and Organisation, 19(5), 508-531. https://doi.org/ 10.1111/j.1468-0432.2012.00607.x
Watts, L. L., Frame, M. C., Moffett, R. G., Van Hein, J. L., \& Hein, M. (2015). The relationship between gender, perceived career barriers, and occupational aspirations. Journal of Applied Psychology, 45, 10-22. https://doi.org/10.1111/jasp.12271

Wichert, I., \& Steele, P. (2013). Data inspiring action: Getting to the heart of women's career progression. Strategic HR Review, 12(3), 126-131. https://doi.org/10.1108/ 14754391311324471

Williams, C. L., Muller, C., \& Kilanski, K., (2012). Gendered organisations in the new economy. Gender and Society, 26(4), 549-573. https://doi.org/10.1177/0891243 212445466

Woolnough, H., \& Redshaw, J. (2016). The career decision of professional women with dependent children: What's changed. Gender in Management: An International Journal, 31(4), 297-311. https://doi.org/10.1108/GM-03-2016-0038

Wyatt, M., \& Silvester, J. (2015). Reflections on the labyrinth: Investigating black and minority ethnic leaders' career experiences. Human Relations, 68(8), 1243-1269. https://doi.org/10.1177/0018726714550890

Zungu, L. I. (2013). South African guideline for the selection and provision of personal protective equipment for women in mining. Occupational Health Southern Africa, 19(3), 4-9. 